\section{The Medical Monopoly on Assisted Suicide}

\author{
Jasper Doomen* \\ School of Law, Open University, Heerlen, Netherlands
}

\begin{abstract}
This article focuses on the legality of euthanasia and assisted suicide in The Netherlands. Euthanasia and assisted suicide are allowed in certain cases, but there is no consensus with respect to the extent of the situations in which physicians should not be prosecuted. I argue that the individual, and, more specifically, his suffering, should be the focal point, and that the present legislation falls short in this respect; no solution can as yet be offered to individuals whose suffering cannot be resolved through medical means and which cannot be subsumed under the terms the law specifies.
\end{abstract}

\section{Introduction}

That the interests of the individual should in principle be guiding in medical practice is not seriously questioned by anyone ${ }^{1}$. The way in which psychiatrists and other physicians are to treat the individual and which options should be open to the individual, by contrast, continues to be an important topic of debate. Termination of life on request and assisted suicide are illegal on the basis of articles 293 and 294 of the Dutch Criminal Code, but physicians are not punished as long as they adhere to the following criteria, specified in the Termination of Life on Request and Assisted Suicide Act.

- The physician must hold the conviction that the request by the patient was voluntary and well-considered

- The physician must hold the conviction that the patient's suffering was lasting and unbearable; has has informed the patient about the situation he was in and about his prospects

*Corresponding author: Jasper Doomen, School of Law, Open University Heerlen, Netherlands, Tel: +31 718872901; E-mail: jasperdoomen@yahoo.com

Citation: Doomen J (2018) The Medical Monopoly on Assisted Suicide. J Psychiatry Depress Anxiety 4: 014.

Received: January 26, 2018; Accepted: March 13, 2018; Published: March 27, 2018

1. I say 'in principle', for in some cases difficult choices must be made. For example, it has recently been debated whether the medication to treat Pompe disease, Fabry disease and Cystic fibrosis, which is relatively costly and used by very few patients, should continue to be paid collectively. Such issues will presumably increasingly be raised as medical progress is made.
- The physician and the patient hold the conviction that there was no other reasonable solution for the situation he was in

- The physician has consulted at least one other, independent physician who has seen the patient and has given his written opinion on the requirements of due care, referred to in parts a-d

- The physician has terminated a life or assisted in a suicide with due care

Similar laws as those which apply in The Netherlands have been adopted in Belgium and Luxembourg. In both countries, just as in The Netherlands, doctors are exclusively allowed to euthanize; in addition, they have to adhere to strict criteria, which do not differ significantly from those that apply in The Netherlands. An important respect in which these three countries differ from others that allow euthanasia is that euthanasia on non-terminally ill patients is legal. With respect to assisted suicide, by contrast, there are important differences between Belgium and The Netherlands. The Belgian law does not provide criteria under which circumstances it would be allowed, from which it may be inferred that it is not allowed, but the issue has raised doubts and debate [1].

The number of euthanasia requests in The Netherlands has increased, the official reports having risen from 3316 cases in 2010 to 6091 in 2016 . The vast majority of these requests have a somatic cause; a psychiatric reason was reported in $1 \%$ or fewer of the cases in each year [2]. A complicating factor is that in these cases, various symptoms converge: "Psychiatric patients do not only suffer from psychological symptoms, but also from general and specific physical and/or psychosomatic symptoms" [3]. Belgium, too, shows an increase in psychiatric euthanasia cases [4].

A known proponent of a perspective in which the right of self-determination is not decisive is the Belgian philosopher Herman de Dijn, who states: "The euthanasia act displays a profound opposition in our society, a struggle between conceptions of man and ideas about ethics that cannot be resolved by having everyone act in accordance with his or her own ideas. According to its opponents, the euthanasia act conveys a dangerous message: That certain lives are no longer worthwhile" [5]. This is not the proper place to extensively evaluate the arguments for the various positions. I will instead focus on the individual's confrontation with his suffering, in order to ascertain to what extent the current Dutch legislation meets the demand that this suffering should be terminated. What is said here may also be of interest for readers who do not live in The Netherlands, for the theme that is discussed here is not particular to a specific country.

\section{An Evaluation of the Legislation}

The Termination of Life on Request and Assisted Suicide Act, which is based on articles 293 and 294 of the Dutch Criminal Code and specifies under which conditions terminating the life of another person at that other person's express and earnest request or intentionally assisting in the suicide of another person or providing that person with the means thereto is not punishable, has recently been re-evaluated; the problems that individuals whose suffering cannot be medically treated or even diagnosed face was discussed at length. It is this suffering I 
wish to address here. The crucial criterion in the law is that there must be 'lasting and unbearable' suffering, to be determined by a physician [6]; the exemption only applies to physicians [7]. It should be noted that unbearableness is "[...] a highly subjective and difficultly objectifiable factor" [8]. This given does not derogate from the fact that the assessment is still medical, which serves as a justification for the monopoly of doctors to act when the termination of life is concerned. This monopoly is, however, as I will argue, problematic in a number of cases.

'Unbearable suffering' may be interpreted broadly, covering both pain and (inter alia) "increasing dependence, an ever greater loss of dignity or the prospect of a gruesome death" [9]. Yet the government does not go so far as to deem the prospect of suffering lasting and unbearable, inter alia as 'lasting' and 'unbearable' are indivisibly linked [10]: "The mere prospect of suffering, irrespective of whether this will result from pain, loss of dignity or fear of an undignified death, cannot, in light of the above, be characterized as lasting and unbearable suffering" [10]. It becomes apparent from the evaluation that the fact that precisely that prospect is oftentimes the motive behind requests for euthanasia constitutes an important problem: "If one examines the reasons why people make a request to be euthanized, pain appears to be a factor in only a small number of requests. In actuality, what drives the request is almost always the loss of dignity that is to be expected" [11].

If this is correct, it is justified to say that the present legislation is not adequate to realize the desired goal. The problems will possibly increase with the impending population ageing. Research shows that a growing number of elderly people imagine themselves requesting euthanasia or having a suicide pill available [12]. The introduction of such a pill is, however, at least for the foreseeable future, a politically sensitive issue. In any event, world-weariness is not a recognized criterion to allow euthanasia or medical assistance in ending one's own life [13] and neither is a 'finished life' [14].

A reform in this respect is pleaded by, amongst others, those who support the Citizens' Initiative Finished Life ('Burgerinitiatief voltooid leven') [15]. In the wake of this initiative, political party Democrats 66 has submitted the bill Dignified End of Life ('Waardig Levenseinde'), but this only pertains to people of 75 years or older. If the pill is only made available to the elderly-leaving the issue of what the precise age limit should $b^{2}{ }^{2}$-, no solution has been offered to young people who face the same problem. Their position remains outside the purview of the law. This subject matter particularly lends itself to a medical ethical reflection, since the questions to which the subject matter gives rise cannot be answered by the medical profession itself [16].

This became clear in a case in which a general practitioner was found guilty of having assisted the suicide of a patient because the main criteria for medically assisted suicide had not been met, namely, that there has to be (in accordance with was indicated above) 'lasting and unbearable' suffering; he was discharged, however, as the act, while principally punishable, did not merit a punishment in this case. As the Dutch Supreme Court expresses it: "The integral care which is to be provided by a general practitioner to patients [...] may result in him being assigned with the task to alleviate the suffering of a patient

2 It is difficult to generalize, and for some people the prospect of having to live until the age of 75 may be dreadful while others may welcome the possibility to live (well) beyond that age. which is not or not predominantly caused by a somatic or mental condition, but which is the consequence of the lack of a life perspective. Given, however, that that physician then enters into a domain that lies beyond his professional competence, he may not, in his capacity of medical professional, form a judgment regarding the unbearableness, lastingness and untreatableness of that suffering" [17].

The question is, then, what, if any, recourse may be available to an individual who is confronted with suffering that cannot be qualified in medical terms, i.e., a case where neither depression nor a physical illness is diagnosed. In cases of 'existential suffering' the Supreme Court commands that a physician "consult others who may be helpful in finding a meaningful fulfillment of one's daily existence" [18]. Who these 'others' might be is not elucidated and this may differ from one case to the next, so that a problem of referral will ensue (should a priest, rabbi or humanistic counselor-to mention just a few possibilities-be approached?). More importantly, no solution is provided for someone for whom, in spite of the availability of such possible alternative support, no meaningful fulfillment can be found [19]. This is not to be taken as criticism of the Supreme Court; the possibility to provide adequate support in such cases simply does not exist at the moment. Steven Pleiter, director of the End-of-life Clinic ('Levenseindekliniek'), expresses the problem as follows: "We, too, face patients who 'suffer from life'-that is what we call it-and who have become detached [...]. We cannot aid these patients under the present standard, since it is based on the presence of medical suffering. At times, dire situations occur, in which elderly people gravely suffer from life. In my view a proper solution should be available in such cases. The present Euthanasia legislation does not offer such a solution" [20].

\section{Towards a Solution}

What is the best way to approach this problem? It must, first of all, be acknowledged that removing lasting suffering in some cases is tantamount to ending the life of the individual, namely, in those cases where suffering from life itself is concerned: The suffering permeates life to such a degree that it is no longer acceptable. The only one who is able to determine this highly subjective given is the individual: It is no longer acceptable to him or her.

In order to accommodate people whose suffering is not covered by the Termination of Life on Request and Assisted Suicide Act it is necessary to change article 294, section 2, of the Dutch Penal Code. This article penalizes, as was pointed out above, assisted suicide; only physicians who observe the demands specified in the Termination of Life on Request and Assisted Suicide Act exempted. In order to confront the problems while acknowledging that some cases do not concern medical issues, non-physicians should also be exempted from punishment. ${ }^{3}$ Certain precautions should obviously be in place; crucially, it must be clear that there is a genuine death wish. With this in mind, one may argue that a physician still has a role to play: "If physicians' professional expertise enables them to deal with the existential questions arising in connection with VE [Voluntary Euthanasia] and PAS [Physician-Assisted Suicide] based on suffering caused by illness or injury-as the conventional view presupposes that it does-it would be inconsistent to deny VE and PAS for persons in purely existential

3 The cooperative Coöperatie Laatste Wil ('Last Will Cooperation') has announced that it will communicate the details of an easily obtainable means to end one's life without pain to its members; there is no consensus among lawyers as to whether this is legal. 
distress by claiming that physicians' professional expertise does not extend to existential questions" [21].

Young's solution, to have both a physician and a non-medical, professional counsellor assess individual cases, may, since he argues that if consulting the latter does not change the outlook of the person requesting assisted suicide this should be allowed [22], be advisable. In any event, it must be borne in mind that assisted suicide is still suicide (killing oneself). It would be both peculiar and undesirable to penalize assisted suicide if suicide (or attempted suicide) is not [23].

\section{Conclusion}

The evaluation of the Termination of Life on Request and Assisted Suicide Act makes it clear that no adequate solution may be offered to elderly people who are 'through with life'. If they suffer unbearably and lastingly, euthanasia or assisted suicide may be granted to them on the basis of a medical assessment, but it may be questioned whether these possibilities are sufficient. Perhaps even more pressing are the problems that are not limited to the elderly, where individuals who 'suffer from life' are concerned: their suffering cannot be gauged from a medical point of view, let alone be treated. The physician's role is limited in this respect, which means that individuals have, on the basis of the present legislation, few to no options to have their suffering-and thereby their lives-terminated. By regulating assisted suicide it may become possible to find a solution for the dire cases whose suffering must at present last unabated.

\section{References}

1. Nys H (2017) A discussion of the legal rules on euthanasia in Belgium briefly compared with the rules in Luxembourg and The Netherlands. In: David Albert Jones, Chris Gastmans, Calum Mackellar (eds.). Euthanasia and Assisted Suicide, Cambridge University Press, Cambridge, England. Pg no: 5-6.

2. https://www.knmg.nl

3. Verhofstadt M, Thienpont L, Peters GY (2017) When unbearable suffering incites psychiatric patients to request euthanasia: Qualitative study. $\mathrm{Br}$ J Psychiatry 211: 238-245.

4. Lopez-Castroman J (2017) About the practice of psychiatric euthanasia: A commentary. BMC Medicine 15: 125.

5. De Dijn H (2011) Euthanasie: een cultuurfilosofische analyse. Ethische Perspectieven, Zoetermeer, Netherlands. Pg no: 71-87.
6. Parliamentary Documents: House of Representatives (1993/1994), Pg no: 1: 4-5.

7. Articles 293 and 294 of the Dutch Criminal Code.

8. Parliamentary Documents: House of Representatives (1993/1994), Pg no: 1: 5 .

9. Parliamentary Documents: House of Representatives (1999/2000), Pg no: 6: 70 .

10. Parliamentary Documents: House of Representatives (1999/2000), Pg no: 6: 60 .

11. Parliamentary Documents: House of Representatives (2013/2014), Pg no: 8: 13.

12. Buiting H, Deeg D, Knol D, Ziegelmann J, Pasman R, et al. (2013) Opvattingen van ouderen over levensbeëindiging. Huisarts Wet 56: 102-105.

13. Parliamentary Documents: House of Representatives (2007/2008), Pg no: 3: 4-6.

14. Parliamentary Documents: House of Representatives (1999/2000), Pg no: 6: $30-60$.

15. Parliamentary Documents: House of Representatives (2013/2014), Pg no: $8: 3$.

16. Bozzaro C (2015) Der Leidensbegriff im medizinischen Kontext: Ein Problemaufriss am Beispiel der tiefen palliativen Sedierung am Lebensende. Ethik in der Medizin 27: 93-106.

17. Dutch Supreme Court (2002) 167: 2-8.

18. Dutch Supreme Court (2002) 167: 5.

19. Parker M (2012) Words and reasons: Psychiatry and assisted suicide. Aust N Z J Psychiatry 46: 80-83.

20. Parliamentary Documents: House of Representatives (2013/2014), Pg no: 8: 9.

21. Varelius J (2012) Medical expertise, existential suffering and ending life. J Med Ethics 40: 104-107.

22. Young R (2014) 'Existential suffering' and voluntary medically assisted dying. J Med Ethics 40: 108-109.

23. Macdonald M (1986) The secularization of suicide in England, 16601800. Past Present 111: 50-110. 